\title{
HUBUNGAN REWARD DAN IKLIM KERJA DENGAN EFEKTIVITAS TIM KERJA GURU SMP NEGERI DI KECAMATAN BEKASI UTARA KOTA BEKASI
}

\author{
Dini Wiandini*
}

\begin{abstract}
The objective of this research is to know the relationship of reward and work climate with teacher work team effectiveness of State Junior High School in sub district of North Bekasi at the district of Bekasi.The research is done to the teachers of State Junior High School in the sub district of North Bekasi at the District of Bekasi by using the survey method. Framed population of this research are 225 teachers. Based on Slovin's formula, there are 144 samples which are taken by combining the Random Sampling,Proportional Sampling, and Area Sampling. The data of each variable are gotten by instrument namely questionare. It is processed by the regression and correlation analytical technique to describe the correlation among the variables. The result of this research concludes that there are positive relationship between (1) reward with team effectiveness, (2) work climate with team effertiveness, and (3) reward and work climate as together with team effectiveness.
\end{abstract}

Key words: Reward, work climate, work team effectiveness

\section{PENDAHULUAN}

Keberhasilan organisasi dalam mencapai tujuannya pada umumnya dapat diukur dengan tingkat efektivitas organisasi tersebut dalam proses pencapaian tujuan organisasi. Pada organisasi sekolah terdapat beberapa kelompok manusia yang saling berinteraksi dalam mewujudkan tujuan sekolah. Kelompok-kelompok tersebut diantaranya kelompok siswa, guru, karyawan tata usaha, petugas kebersihan, petugas keamanan, serta orang tua siswa dengan Kepala Sekolah sebagai pemimpin sekolah yang akan berinteraksi pula dengan masyarakat sekitar sekolah. Guru merupakan salah satu komponen pendidikan yang sangat berperan dalam pencapaian visi, misi, dan tujuan sekolah. Keberadaan guru sebagai ujung tombak pelaksana pendidikan di kelas merupakan aspek penting bagi keberhasilan sekolah. Guru yang melaksanakan tugasnya dengan tingkat kinerja yang tinggi dan professional, dapat meningkatkan mutu proses pembelajaran yang selanjutnya dapat meningkatkan prestasi siswa. Pelayanan pembelajaran yang berkualitas merupakan harapan siswa dan orang tua sebagai pelanggan eksternal sekolah.

Dalam konteks organisasi, guru di sekolah merupakan bagian dari tim kerja sekolah yang memiliki peran penting dalam menciptakan sekolah yang efektif sehingga tujuan sekolah dapat tercapai. Dengan demikian melalui proses manajemen yang bermutu, efektivitas guru dalam melaksanakan tugasnya baik secara individu maupun kelompok sangat diperlukan dalam upaya mempercepat tercapainya visi dan misi sekolah .

Salah satu komponen terciptanya manajemen mutu terpadu pendidikan adalah adanya kerjasama tim dari anggota-anggota organisasi. Guru-guru merupakan tim-tim kerja yang perlu dioptimalkan efektivitasnya sehingga dapat mempermudah pencapaian tujuan organisasi. Namun demikian, berkaitan dengan keefektifan sekolah kenyataan menunjukkan bahwa kelemahan utama dalam manajemen pendidikan

\footnotetext{
* Kepala Sekolah SMP Negeri 21 Kota Bekasi
} 
adalah pada tim kerja yang tidak solid sehingga efektivitas tim kerja guru di banyak sekolah masih rendah.

Rendahnya efektivitas tim kerja guru di sekolah seperti yang terjadi di SMP Negeri yang berada di wilayah Kecamatan Bekasi Utara misalnya SMP Negeri 21 Bekasi, diantaranya disampaikan oleh Kepala Sekolah dan Wakil Kepala Sekolah bidang akademik SMP Negeri tersebut. Berdasarkan jawaban atas pertanyaan penulis tentang efektivitas tim kerja guru, Wakil Kepala SMP Negeri 21 Bekasi mengatakan, "efektivitas tim kerja guru di SMP Negeri 21 Bekasi masih rendah, sebagai contoh, hal ini ditunjukkan pada masih sedikitnya jumlah guru yang mengumpulkan program pembelajaran sesuai dengan waktu yang ditargetkan oleh sekolah."

Kondisi seperti diuraikan di atas, menunjukkan betapa lemahnya efektivitas tim kerja guru di sekolah. Guru tidak memiliki semangat kerjasama yang memadai. Hal ini berimplikasi pada lemahnya manajemen institusi. Tujuan dan target pencapaian visi dan misi sekolah menjadi tidak jelas karena tim kerja guru yang lemah.

Berdasarkan uraian di atas, maka dapat dipahami bahwa terdapat kesenjangan antara kondisi ideal yang diharapkan dengan kondisi yang terjadi di sekolah berkaitan dengan efektivitas tim kerja guru. Penelitian ini akan memusatkan perhatian terhadap efektivitas tim kerja guru dengan mengkaji faktor-faktor yang diduga mempunyai hubungan dengan efektivitas tim kerja guru dalam melaksanakan tugas pokoknya di sekolah. Tempat penelitian di SMP Negeri yang berada di wilayah kecamatan Bekasi Utara Kota Bekasi.

\section{Efektivitas Tim Kerja}

Stephen P.Robbins dan Timothy A. Judge (2007:357) membedakan pengertian kelompok kerja dengan tim kerja, "a work group that interacts primarily to share information and to make decisions to help each member perform within his or her area of responsibility." Kelompok kerja adalah kelompok yang berinteraksi terutama untuk berbagi informasi dan membuat berbagai keputusan untuk membantu setiap anggota bekerja di dalam area tanggung jawabnya. Kelompok kerja hanya merupakan gabungan akhir dari kontribusi setiap anggota kelompok, sedangkan, "a work team generates positive synergy through coordinated effort. The individual efforts result in a level of performance that is greater than the sum of those individual inputs." Tim kerja merupakan kelompok yang usahausaha individualnya menghasilkan kinerja yang lebih tinggi dari pada jumlah masukan individual.

Mengenai pengertian efektivitas tim kerja dikemukakan pula oleh Procter \& Gamble's former CEO A. G. Lafley (2011:168) bahwa "team effectiveness comes together when you have "the right players in the right seats on the same bus, headed in the same direction." Efektivitas tim datang bersama-sama ketika Anda memiliki "hak pemain di kursi tepat di bus yang sama, menuju ke arah yang sama. Pendapat ini dapat diartikan bahwa efektivitas tim kerja dapat dicapai bila setiap anggota tim memberikan kontribusi yang sama untuk mencapai arah atau tujuan yang telah ditetapkan bersama. Selanjutnya, John R Schermerhorn, et all berpendapat bahwa, dalam perilaku organisasi sebuah tim yang efektif didefinisikan sebagai salah satu yang dapat mencapai kinerja tugas yang tinggi,

kepuasan anggota dan kelangsungan hidup tim. Lebih lanjut Schermerhorn dan Hunt (2011:168) menjelaskan tentang kriteria pada efektivitas tim yaitu, "with regard to task performance, an effective team achieves its performance goals in the standard sense of quantity, 
quality, and timeliness of work results. For a formal work unit such as a manufacturing team this may mean meeting daily production targets. For a temporary team such as a new policy task force this may involve meeting a deadline for submitting a new organizational policy to the company president". Berkaitan dengan kinerja tugas, tim yang efektif mencapai kinerja tujuan dalam arti standar kuantitas, kualitas, dan ketepatan waktu hasil kerja. Untuk unit kerja formal seperti tim manufaktur ini berarti memenuhi target produksi harian. Untuk tim sementara seperti gugus tugas kebijakan baru ini mungkin melibatkan pertemuan batas waktu untuk menyerahkan kebijakan organisasi baru kepada pimpinan organisasi.

Stephen P. Robbins (2007:362) berpendapat bahwa tim yang efektif dapat berhubungan dengan beberapa komponen yaitu: komponen sumber dan pengaruh kontekstual, komposisi tim, rancangan kerja, dan variabel proses, seperti yang digambarkan dalam model efektivitas Tim (Team Effectiveness Model) berikut ini:

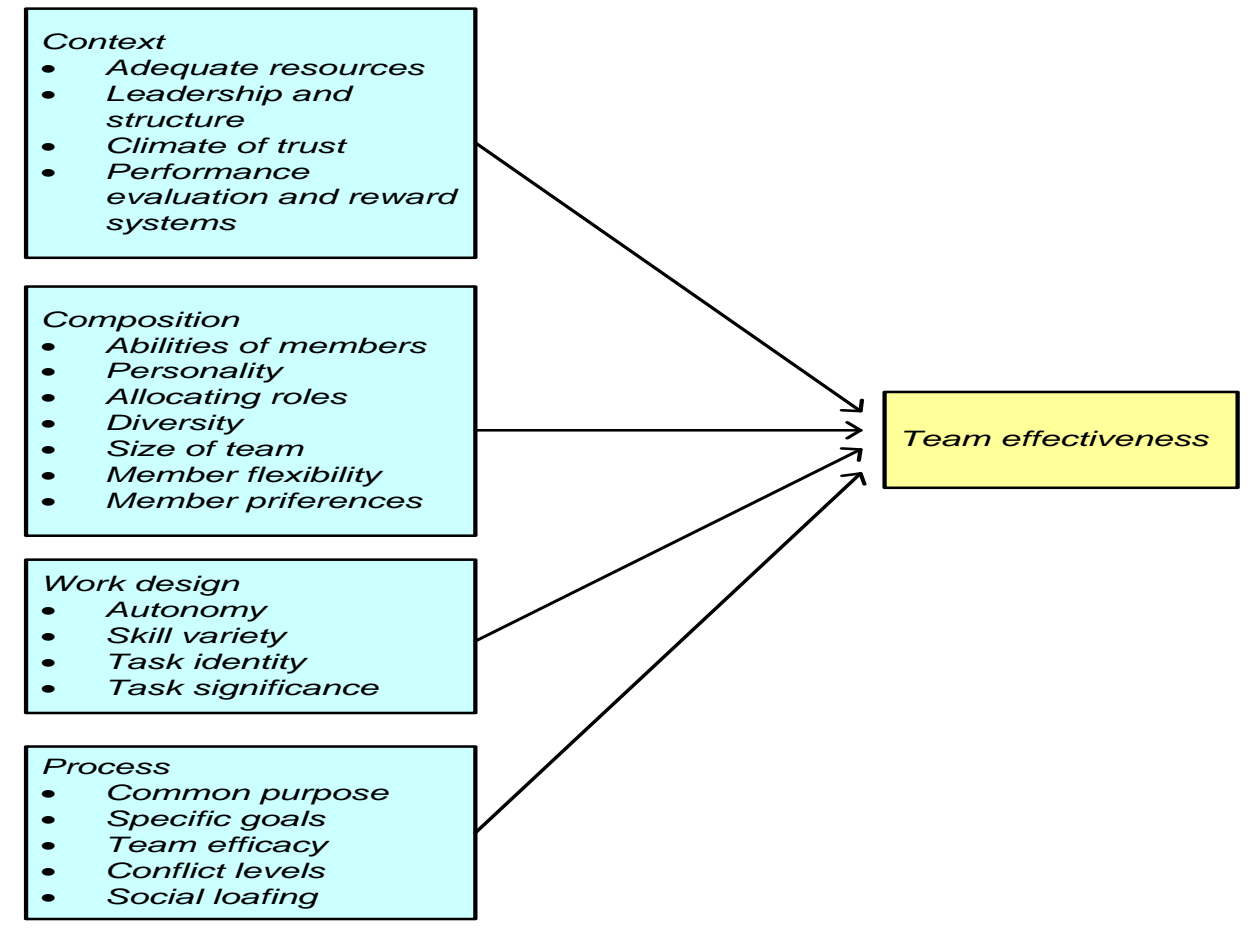

Gambar 1: Team Effectiveness Model

Model teoritik di atas menjelaskan bahwa efektivitas tim kerja berhubungan dengan komponen-komponen sumber daya yang memadai, kepemimpinan dan struktur kerja, iklim kepercayaan atau iklim kerja, evaluasi kinerja, sistem penghargaan, kemampuan para anggota, kepribadian, pengalokasian peran, keragaman keterampilan dan pengetahuan, ukuran tim, fleksibilitas anggota dalam menyelesaikan tugas anggota lainnya, preferensi anggota dalam tim, rancangan kerja, tujuan umum, tujuan khusus, rasa percaya diri akan keberhasilan tim, tingkat konflik, dan kemalasan sosial.

Berdasarkan uraian di atas, dapat disintesiskan efektivitas tim kerja adalah pencapaian hasil dari pemusatan terhadap tugas yang dilakukan oleh tim kerja yang ditandai oleh indikator-indikator: (1) ketercapaian tujuan, (2) ketercapaian kualitas kerja, (3) ketepatan waktu dalam penyelesaian tugas, (4) keterkaitan sesama anggota tim (interdependence), (5) ketercapaian hasil kerja. 


\section{Reward}

Menurut Laura Schendell (2007:268), “important work rewards can be both intrinsic and extrinsic. Rewards are intrinsic in the form of employee recognition programs and extrinsic in the form compensation system." Penghargaan pekerjaan yang penting bisa berupa penghargaan intrinsik dan ekstrinsik. Penghargaan intrinsic dapat berupa program pengakuan karyawan dan penghargaan ekstrinsik dapat berupa sistem kompensasi.

Lebih rinci tentang konsep reward dikemukakan oleh Fred (2007:97) Luthans bahwa, "there are two basic types of "pay-for-performance" plans individual incentive plans and group incentive plants." Terdapat dua jenis dasar dari metode imbalan untuk kinerja, yakni metode insentif individu dan metode insentif kelompok. Metode insentif individu memberi imbalan kepada karyawan berdasarkan hasil atau kualitas kerja bisa dalam bentuk gaji, bonus, komisi, dan opsi saham. Sedangkan metode insentif kelompok ada tiga macam yaitu: (1) pembagian hasil (gain sharing) yaitu metode yang dirancang untuk berbagi penghematan biaya yang berasal dari peningkatan produktivitas pada tim, (2 pembagian keuntungan (profit sharing), dan (3) metode yang memungkinkan karyawan secara bertahap menambah saham kepemilikan perusahaan (employee stock ownership plan atau ESOP).

Gibson, et al, mengemukakan bahwa (2006:177), "ay system based on competencies and contributions made, team-based incentives, and rewards focusing on improved results are becoming more widely considered and implemented systems." Sistem penghargaan berbasis pada kompetensi dan kontribusi, insentif berbasis tim, dan reward yang berfokus pada hasil menjadi sistem yang dianggap lebih luas untuk diterapkan. Menurut Luthans (2008:99) Metode insentif kelompok semakin popular yang dilandasi dengan pertimbangan bahwa, "organizations are increasingly aware that teams and teamwork can lead to higher productivity and better quality than do individuals working on their own." Organisasi semakin menyadari bahwa tim dan kerja tim dapat menghasilkan produktivitas lebih tinggi dan berkualitas

lebih baik daripada pekerjaan individu. Sedangkan tujuan program reward menurut Gibson, et al (2006:177) adalah, "(1) to attract qualified people to join the organization, (2) to keep employees coming to work, and (3) to mitivate employees to achieve high level of performance." Tujuan utama dari program reward adalah (1) untuk menarik orang yang memenuhi syarat untuk bergabung dengan organisasi, (2) untuk menjaga karyawan datang bekerja, dan (3) untuk memotivasi karyawan untuk mencapai tingkat kinerja yang tinggi.

Berdasarkan uraian di atas, dapat disintesiskan reward adalah penghargaan yang diterima oleh seseorang, atas prestasi dari pekerjaannya baik sebagai individu maupun sebagai anggota tim kerja, dengan indikator: (1) imbalan, (2) pengakuan diri, (3) penghormatan, dan (4) promosi jabatan.

\section{Iklim Kerja}

Menurut Davis seperti yang dikutip oleh Husaini Usman (2009:202) ialah, "the human environment within an organization's employees do their work." Pernyataan ini mengandung pengertian bahwa iklim organisasi adalah lingkungan manusia yang ada di dalam suatu organisasi tempat mereka melaksanakan pekerjaannya. Dari kedua teori di atas dapat dikatakan bahwa Iklim organisasi adalah kumpulan dari persepsi karyawan termasuk mengenai pengaturan karyawan, keinginan dari pekerjaan dalam organisasi, dan lingkungan sosial dalam organisasi. Jadi iklim organisasi merupakan harapan-harapan serta cara pandang individu terhadap organisasi. 
Sejalan dengan pengertian iklim organisasi, pendapat tentang iklim kerja dikemukakan oleh Bennis and Schein (2005:52), "to improve a work climate, it helps to understand how climate aff ects people and how it develops. A positive work climate stimulates staff motivation because it provides conditions under which people can pursue their own goals while striving toward organizational objectives." Pendapat ini dapat diartikan bahwa meningkatkan iklim kerja,dapat membantu untuk memahami bagaimana iklim manusia mengalami perkembangan. Sebuah iklim kerja yang positif merangsang motivasi pegawai karena dapat memberikan kondisi-kondisi dimana orang dapat mengejar tujuan mereka sendiri yang selanjutnya berusaha menuju tercapainya tujuan organisasi.

Pengertian mengenai iklim kerja diuraikan pula oleh Sarah Johnson and Greg Rodway (2005:52), "work Climate is the prevailing workplace atmosphere as experienced by employees. It is what it feels like to work in a group." Iklim kerja adalah suasana tempat kerja yang umum dialami oleh pegawai. Seperti apa yang dirasakan dalam tim kerja. Selanjutnya Litwin dan Stringer (2008:133) menyebutkan sembilan dimensi iklim kerja yaitu: "struktur, tanggung jawab, imbalan, risiko, kehangatan, dukungan, standar, konflik, dan identitas."

Pendapat mengenai hubungan iklim kerja dengan efektivitas tim kerja yang didasarkan pada hasil penelitian para ahli sebelumnya, diberikan oleh Ilke Inceoglu (2002:45) yang mengatakan bahwa, "the exact mechanisms between climate and organizational outcomes have not been clucidated yet but a number of studies have produced evidence that climate is related to effectiveness." Yang artinya mekanisme yang tepat antara hasil iklim dan organisasi belum dievaluasi, tetapi sejumlah studi telah menghasilkan bukti bahwa iklim berkaitan dengan efektivitas.

Berdasarkan uraian di atas, dapat disintesiskan bahwa yang dimaksud dengan iklim kerja adalah suasana kerja yang ada pada lingkungan sekitar dengan indikator: (1) adanya kejelasan aturan; (2) kejelasan tanggung jawab; (3) kejelasan peran; (4) ketersediaan fasilitas untuk bekerja, (5) kesempatan mengembangkan kemampuan; (6) keterlibatan dalam pengambilan keputusan, (7) kesempatan yang mampu memberikan tantangan untuk mengembangkan cara kerja.

\section{METODE}

Penelitian ini menggunakan metode survey dengan pendekatan korelasional. Penelitian ini dilakukan selama dua bulan yaitu pada bulan September sampai dengan Oktober 2011. Penelitian dilaksanakan pada SMP Negeri yang berada di wilayah Kecamatan Bekasi Utara Kota Bekasi, yang terdiri dari lima sekolah negeri. Kelima sekolah negeri tersebut adalah: (1) SMP N 21 Bekasi sebanyak 57 orang guru, (2) SMP N 38 Bekasi sebanyak 36 orang guru, (3) SMP N 5 Bekasi sebanyak 54 orang guru, (4) SMP N 25 Bekasi sebanyak 48 orang guru, (5) SMP N 37 Bekasi sebanyak 30 guru. Populasi terjangkau penelitian ini sejumlah 225 orang guru yang terdiri dari guru di SMP N 21, SMP N 5, SMP N 38, SMP N 25, dan SMP Negeri 37 Bekasi. Sampel penelitian adalah sebanyak 144 orang. 


\section{HASIL DAN PEMBAHASAN}

\section{Hubungan Reward dengan Efektivitas Tim Kerja}

Hasil analisis korelasi sederhana antara reward dengan efektivitas tim kerja, diperoleh koefisien korelasi sebesar 0,626 (ry1 = 0,626). Koefisien determinasi (r2y1) adalah sebesar 0,392. Ini menunjukkan 39,2\%.

Hasil perhitungan koefisien korelasi parsial menunjukkan ry1.2 sebesar 0,261. Dengan demikian keterkaitan antara reward dengan efektivitas tim kerja sangat tinggi dan positif, artinya semakin baik reward diharapkan semakin tinggi pula tingkat efektivitas tim kerja guru. Demikian pula sebaliknya, semakin buruk reward maka semakin rendah tingkat efektivitas tim kerja guru.

Apabila dikaitkan dengan teori tentang hubungan antara reward dengan efektivitas tim kerja seperti ditulis oleh Schemerhorn et all (2011:169) mengatakan, "appropriate goals, well-designed reward systems, adequate resources, and appropriate technology are all essential to support the work of teams. Just as an individual's performance, team performance can suffer when goals are unclear, insufficiently challenging, or arbitrarily imposed. It can also suffer if goals and rewards are focused too much on individual-level instead of group-level accomplishments". Teori di atas menjelaskan bahwa tujuan yang tepat, sistem reward yang dirancang dengan baik, sumber daya yang memadai, dan teknologi yang tepat berperan penting dalam mendukung kerja tim. Seperti halnya pada kinerja individu, kinerja tim akan menurun jika tidak ada kejelasan tujuan, tujuan kurang menantang dan adanya kesewenang-wenangan. Penurunan kinerja tim juga dapat terjadi bila tujuan dan penghargaan yang diberikan berfokus pada pencapaian individual dan tidak difokuskan pada tingkat pencapaian tim.

\section{Hubungan Antara Iklim Kerja dengan Efektivitas Tim Kerja}

Hasil analisis korelasi sederhana antara reward dengan efektivitas tim kerja, diperoleh koefisien korelasi sebesar 0,636 (ry2 =0,636). Dengan demikian koefisien korelasi $r_{\mathrm{y} 2}$ sangat signifikan. Koefisien determinasi adalah sebesar 0,405 ini menunjukkan bahwa 40,5\% variasi yang terjadi pada efektivitas tim kerja dapat dijelaskan oleh variasi iklim kerja. Hasil perhitungan koefisien korelasi parsial menunjukkan ry2.1 sebesar 0,298.

Dengan demikian, dapat disimpulkan jika dilakukan pengontrolan terhadap variabel reward $\left(X_{1}\right)$, iklim kerja $\left(X_{2}\right)$ mempunyai hubungan positif dan sangat signifikan dengan efektivitas tim kerja $(\mathrm{Y})$.

Apabila dikaitkan hasil penelitian dengan teori hubungan antara iklim kerja dengan efektivitas tim kerja seperti yang uraikan oleh Thompson (2007:7), "outlines that effective organizations must possess the ability to use multiple frames in organizational policy and procedure, and conversely, reliance of any one or two frames will not lead to effective organizational performance or a conducive climate to achievement of envisioned results; in this case for the advancement of women in science".

Pendapat di atas menguraikan bahwa organisasi yang efektif harus memiliki kemampuan untuk menggunakan beberapa langkah dalam kebijakan organisasi dan prosedur, dan sebaliknya, ketergantungan dari setiap langkah satu atau dua tidak akan mengarah pada kinerja organisasi yang efektif atau iklim yang kondusif untuk pencapaian hasil yang dibayangkan, dalam hal ini untuk kemajuan dalam ilmu pengetahuan. 


\section{Hubungan Antara Reward dan Iklim Kerja Dengan Efektivitas Tim Kerja}

Hasil analisis ganda antara reward dan iklim kerja dengan efektivitas tim kerja, diperoleh koefisien korelasi ganda sebesar 0,472 $\left(\mathrm{r}_{\mathrm{y} \cdot 12}=0,472\right)$. Nilai ini memberikan pengertian bahwa keterkaitan antara reward dan iklim kerja secara bersama-sama dengan efektivitas tim kerja sangat tinggi dan positif. Dengan demikian semakin tinggi reward dan iklim kerja diharapkan semakin tinggi pula tingkat efektivitas tim kerja. Demikian pula sebaliknya, semakin rendah reward dan iklim kerja maka semakin rendah pula tingkat efektivitas tim kerja.

Dari hasil penghitungan, didapat nilai koefisien determinansi sebesar 0,223. Hasil analisis tersebut menunjukkan pengertian bahwa kurang lebih 22,3\% variasi efektivitas tim kerja dapat dijelaskan oleh reward dan iklim kerja secara bersama-sama dengan pola hubungan fungsionalnya seperti ditunjukkan oleh persamaan regresi ganda tersebut di atas. Hal ini memperkuat teori bahwa efektivitas tim kerja ditentukan oleh banyak faktor dan diantara faktor tersebut adalah reward dan iklim kerja. Reward dan iklim kerja secara nyata atau sebesar $22,3 \%$ dapat meningkatkan efektivitas tim kerja. Artinya apabila dilakukan penilaian terhadap reward dan iklim kerja secara bersama-sama dengan efektivitas tim kerja, maka lebih kurang 22,3\% variasi pasangan skor ketiga variabel tersebut akan berdistribusi dan mengikuti pola hubungan antara variabel reward dan iklim kerja secara bersama-sama dengan efektivitas tim kerja.

Ditinjau dari teori tentang efektivitas tim kerja dalam hubungannya dengan reward dan iklim kerja, Stephen P. Robbins (2007:362) mengemukakan bahwa tim yang efektif dapat berhubungan dengan beberapa komponen yaitu : komponen sumber dan pengaruh kontekstual, komposisi tim, rancangan kerja, dan variabel proses.

\section{PENUTUP}

Kesimpulan. Berdasarkan hasil analisa dan kajian dari penelitian ini dapat disimpulkan bahwa:

1) Terdapat hubungan positif antara reward dengan efektivitas tim kerja guru SMP Negeri di Kecamatan Bekasi Utara Kota Bekasi. Penguatan reward sekolah akan meningkatkan efektivitas tim kerja guru.

2) Terdapat hubungan positif antara iklim kerja dengan efektivitas tim kerja guru SMP Negeri di Kecamatan Bekasi Utara Kota Bekasi. Penguatan iklim kerja di sekolah akan meningkatkan efektivitas tim kerja guru.

3) Terdapat hubungan positif antara reward dan iklim kerja secara bersama-sama dengan efektivitas tim kerja guru SMP Negeri di Kecamatan Bekasi Utara Kota Bekasi. Penguatan reward dan iklim kerja di sekolah akan meningkatkan efektivitas tim kerja guru.

Saran. Dari hasil kesimpulan di atas dapat disarankan sebagai berikut:

Bagi Kepala Dinas. (1) Perlu segera diberlakukan ketentuan tentang kewajiban guru PNS untuk bertugas dengan perhitungan 37,5 jam per minggu selama lima hari kerja 
seperti yang telah diberlakukan di Propinsi DKI Jakarta. (2) Untuk pelaksanaan ketentuan di atas, hendaknya Kepala Dinas Pendidikan Kota Bekasi dapat mengupayakan adanya dana tambahan kesejahteraan bagi guru dari Pemerintah Daerah yang cukup memadai sehingga guru lebih termotivasi dalam melaksanakan tugasnya. (3) Perlu adanya pembagian tugas Pengawas Sekolah yang lebih spesifik.

Bagi Pengawas Sekolah. (1) Memberikan pemahaman kepada para kepala sekolah akan pentingnya menyelenggarakan kegiatan-kegiatan yang dapat meningkatkan kompetensi sosial guru sehingga dapat menumbuhkan sikap kerja sama tim bagi guru. (2) Melaksanakan monitoring pelaksanaan kegiatan MGMPS, sehingga dapat dilakukan pembinaan secara berkelompok kepada guru mata pelajaran sejenis. (3) Memberi bimbingan teknis kepada guru tentang pelaksanaan kegiatan yang dapat menumbuhkan iklim kolaboratif dalam pelaksanaan tugas guru, seperti pelaksanaan lesson study.

Bagi Kepala Sekolah. (1) Adanya keterlibatan guru baik secara individu maupun kelompok dalam proses pengambilan keputusan. (2) Melaksanakan komunikasi yang sistematis dan efektif antar warga sekolah dalam rangka meningkatkan iklim kerjasama antar warga sekolah. (3) Melakukan kemitraan dengan orang tua siswa, masyarakat dan dunia usaha serta instansi-instansi pemerintah untuk mengupayakan terpenuhinya sarana dan biaya untuk meningkatkan kenyamanan kerja guru dan reward yang dapat diberikan kepada guru. (4) Memberikan otonomi atau kewenangan kepada tim kerja guru dalam menentukan prosedur kerja untuk meningkatkan mutu pembelajaran. (5) Melaksanakan kegiatan-kegiatan untuk pengembangan empat kompetensi guru yaitu kompetensi kepribadian, pedagogik, professional, dan sosial, baik melalui pendidikan dan pelatihan guru, maupun pelaksanaan kegiatan musyawarah guru mata pelajaran sejenis di tingkat sekolah, atau di tingkat kota.

Bagi Guru. Efektivitas tim kerja guru sangat penting dalam mewujudkan tujuan bersama di sekolah. Guru harus dapat meningkatkan kompetensi atau profesionalismenya sehingga pemberian reward dapat sesuai dengan kinerja yang telah dilakukannya. Dalam hal ini, guru tidak hanya menuntut sekolah untuk memberikan reward, akan tetapi juga mau dan mampu meningkatkan kinerjanya sehingga pantas diberikan reward yang sesuai dengan hasil kerjanya.

\section{DAFTAR RUJUKAN}

Batista, Elena Valentin. Executive Summary, Institutional, Departemental Work Climate and Organizational Culture:Diagnosing for Transformation. Humacao: University Of Puerto Rico, 2007, (http://www.google.com).

Gibson, James L, John M.Ivancevich. Organization behavior structure processes, Twelfth Edition. New York: McGraw -Hill International Edition Companies, Inc, 2006.

Icceoglu, Ilke. Organizational Culture, Team Climate, Workplace Bullying and Team Effectiveness An Empirical Study on their Relationship. Munchen : Herbert Utz Verlag Wissenschaft, 2002, (http://www.google.com).

Johnson, Sarah and Greg Rodway. The Management and Leadership. The Manager Volume 11 Number 3, 2005. (http://www.google.com.). 
Luthans, Fred Luthans. Organizational Behavior, Eleven Edition. New York: McGraw Hill International Edition Companies, Inc, 2008.

Robbin, Stephen P. and Timothy A. Judge. Organization Behavior, 13 ${ }^{\text {th }}$ Edition. New Jersey: Paerson International Edition, 2007.

Schermerhorn, John R. , Hunt, et all. Organizational Behavior, 11 th Edition, International Student Version . Pennsylvania USA ; John Willey \& Sons, Inc, 2011.

Schermerhorn, John R. , Hunt, et all. Organizational Behavior, 11'th Edition, International Student Version. Pennsylvania USA ; John Willey \& Sons, Inc, 2011.

Usman, Husaini .Manajemen, Teori, Praktik, dan Riset Pendidikan, Edisi 3. Jakarta: Bumi Aksara, 2009.

Wirawan. Budaya dan Iklim Organisasi, Teori Aplikasi dan Penelitian. Jakarta : Salemba Empat, 2008. 